\title{
Greater osteoblast densities due to the addition of amphiphilic peptide nanoparticles to nano hydroxyapatite coatings
}

This article was published in the following Dove Medical Press journal: International Journal of Nanomedicine

\author{
Fernando F Rios-Pimentel ${ }^{1}$ \\ Run Chang ${ }^{2}$ \\ Thomas J Webster ${ }^{2}$ \\ Magdalena $M$ \\ Méndez-González ${ }^{3}$ \\ Miguel García-Rocha ${ }^{4}$ \\ 'Nanociencias y Nanotecnología, \\ CINVESTAV-IPN, Ciudad de Mexico, \\ México; ${ }^{2}$ Department of Chemical \\ Engineering, Northeastern University, \\ Boston, MA, USA; ${ }^{3}$ Departamento de \\ Física, ESFM-IPN, Ciudad de Mexico, \\ México; ${ }^{4}$ Departamento de Física, \\ CINVESTAV-IPN, Ciudad de Mexico, \\ México
}

Correspondence: Thomas J Webster Department of Chemical Engineering, Northeastern University, 3/3

Snell Engineering Center, Boston, MA 02115, USA

Tel + I 6173736585

Email th.webster@neu.edu
Background: In vitro and in vivo studies have shown that metallic implants coated with nano hydroxyapatite (HA) reduce the time needed for complete osseointegration compared to metallic implants coated with conventional or micron-sized HA. Moreover, due to their biologically inspired nanometer dimensions, amphiphilic peptide nanoparticles (APNPs) can also promote osteoblast attachment and enhance other cell functions if used as a coating material. Coatings made of HA and APNPs could improve osteoblast functions, but have never been tested.

Purpose: The objective of this study was to prepare coatings of nanocrystalline HA and APNPs on poly(2-hydroxyethyl methacrylate) (pHEMA) coatings in order to improve osteoblast (boneforming cells) adhesion and cell density.

Methods: HA was synthesized by a wet chemical process. Coatings were synthesized with different conditions and components.

Results: X-ray diffraction infrared spectroscopy, transmission electron microscopy, and electron diffraction showed that nanocrystalline HA was synthesized with an expected nano size and shape distribution but with low impurities. pHEMA hydrogels with HA and APNPs increased osteoblast densities after 3 days compared to controls.

Conclusion: Since cell proliferation is a prerequisite function for bone formation, these results imply that the current materials should be tested for a wide range of orthopedic applications.

Keywords: orthopedic applications, XRD, FTIR, TEM, SEM, cell studies

\section{Introduction}

Although metallic implants, especially titanium and its alloys, have high tensile and compressive strength, high corrosion resistance, and high biocompatibility, they do not tend to promote the regeneration of bone at their surfaces and they do not show an ability to support osseointegration over the long term. ${ }^{1-7}$ These metallic implants show high failure rates after 10-15 years of implantation. For instance, in the United States, $11 \%$ of hip replacements and $8 \%$ of knee replacements required revision in $2003 .{ }^{8}$ For this reason, researchers have developed strategies for the modification of the surfaces of metallic implants in order to promote osseointegration. ${ }^{1-4,9}$ An alternative to improve osseointegration and to reduce the wear of bone implants is to apply a surface coating with materials that are similar to those found in natural bone. Calcium phosphates seem to be good candidates for this purpose, as $65 \%$ of the mineral phase of bone is composed of $\mathrm{Ca}_{5}\left(\mathrm{PO}_{4}\right)_{3}(\mathrm{OH})$ (hydroxyapatite [HA]), a calcium phosphate; however, only some calcium phosphates are useful for this purpose, since its solubility increases when its $\mathrm{Ca} / \mathrm{P}$ ratio is reduced. ${ }^{10-12}$ 
Fully crystalline HA is considered the best option to coat metallic implants. ${ }^{1,13-15}$ Several studies have shown that implants coated with HA improved osseointegration compared to non-coated implants. ${ }^{1,3}$ Because nanomaterials possess enhanced physical properties (such as surface reactivity, surface area, and mechanical properties) compared to micron-structured materials (for instance, mechanical properties depend on the amount of defects and this amount is reduced when crystal size is reduced) and that HA present in the human body is nanometric, researchers have widely studied the use of nano HA to coat metallic implants. ${ }^{8}, 16$ Nano HA has shown excellent cytocompatibility properties with osteoblasts. Moreover, in vitro and in vivo studies have demonstrated significant improvements when metallic prostheses are coated with nanocrystalline HA. For example, an in vivo study showed that titanium implants coated with nano HA took only 2 weeks to completely osseointegrate, whereas those implants covered with conventional HA took over 8 weeks. ${ }^{8}$ Yet, despite such promise for the use of HA as a coating material to improve orthopedic implant efficacy, there have been issues with the methods used to coat HA, such as plasma spray deposition where small changes in temperature can cause large variations in chemistry, crystallinity, and so on to influence bone formation.

On the other hand, amphiphilic peptide nanoparticles (APNPs) are non-viral gene delivery vectors which can selfassemble into stable spherical micelles or fibrous structures with hydrophilic shells and hydrophobic cores with aqueous solutions. ${ }^{17}$ APNPs contain the peptide arginine-glycineaspartic acid (RGD) which not only promotes cell attachment but enhances other cell functions such as cell proliferation. We, thus, hypothesized that coating biomaterials with RGDcontaining peptides can be a good strategy for controlling the cell material interface and achieving a bioactive implant. ${ }^{18}$ Moreover, due to their surface energetics, APNPs can improve interactions with HA to provide for an improved metallic coating.

The aim of this study was to promote osteoblast proliferation, a necessary first step to osseointegration; for this, it is desired to obtain poly 2-hydroxyethyl methacrylate (pHEMA) coatings with nano HA and APNPs. In this way, this study was the first to determine whether HA/APNPs should be further studied as a novel orthopedic coating material.

\section{Experimental Synthesis of HA}

A precipitation method was used to synthesize HA, since this is an easy method to set up and operate, and mimics the biomineralization process of bone. ${ }^{8}$ Briefly, $100 \mathrm{~mL}$ of a $0.65 \mathrm{M}$ hydrogen ammonium phosphate (JT Baker, Center Valley, PA, USA) solution was mixed with $1,137.5 \mathrm{~mL}$ of deionized water $\left(\mathrm{dH}_{2} \mathrm{O}\right)$ while $150 \mathrm{~mL}$ of ammonium hydroxide (JT Baker) was used to adjust the $\mathrm{pH}$ of the solution to around 10 . About $135 \mathrm{~mL}$ of a $1 \mathrm{M}$ calcium nitrate tetrahydrate (Fermont, Monterrey, Nuevo Leon, Mexico) solution was slowly dripped into the above mixture. Precipitation continued for 10 minutes at room temperature. The solution was then centrifuged and rinsed with $\mathrm{dH}_{2} \mathrm{O}$. The precipitate was finally dried at $\sim 80^{\circ} \mathrm{C}$ for several hours. This process was repeated several times to obtain the HA needed to prepare the hydrogels. HA was sterilized with UV radiation for 30 minutes. Figure 1 shows a micrograph of the HA obtained demonstrating the characteristic nanometric features found in other studies. ${ }^{8}$

\section{Synthesis of APNPs}

APNPs were prepared as previously described. ${ }^{19}$ Figure 2 shows the chemical structure of the APNPs. APNPs were sterilized for 30 minutes with UV radiation.

\section{HA characterization}

HA powders were characterized by X-ray diffraction (Rigaku Smart Lab, Tokyo, Japan), infrared spectroscopy, transmission electron microscopy (JEOL JEM-2010; JEOL, Tokyo, Japan), and electron diffraction (JEOL JEM-2010; JEOL) following standard methods.

\section{Substrate preparation}

Sixteen Ti6Al4V samples of $1 \times 1 \mathrm{~cm}$ were cut from a tempered Ti6Al4V foil (Goodfellow, Huntingdon, UK) and then polished with $240,320,400,600$, and 1,000 grit sandpaper.

\section{Synthesis of coatings}

A 70\% (v/v) hydroxyethyl methacrylate monomer solution (Sigma-Aldrich Co., St Louis, MO, USA) in water was used to prepare pHEMA coatings on Ti substrates. For the samples incorporated with nanoparticles, HA, APNPs, or both HA and APNPs were added to the monomer solution and sonicated for 15 minutes at room temperature. The final concentrations of HA nanoparticles and APNPs were 14 and $0.5 \mathrm{mg} / \mathrm{mL}$, respectively. Monomer solutions were sonicated for another 30 minutes followed by the addition of $5 \mathrm{mg} / \mathrm{mL}$ azobisisobutyronitrile initiator. Ti substrates were pre-heated at $180^{\circ} \mathrm{C}$ for 30 minutes. Next, $20 \mu \mathrm{L}$ of a freshly prepared monomer solution was added onto each substrate and heated at $180^{\circ} \mathrm{C}$ to allow for polymerization. The coated Ti substrates were washed in deionized water intensively to remove all of the unreacted initiator, sterilized with 70\% ethanol, and dried under UV radiation after being washed with PBS ( $\mathrm{pH}$ 7.4). 


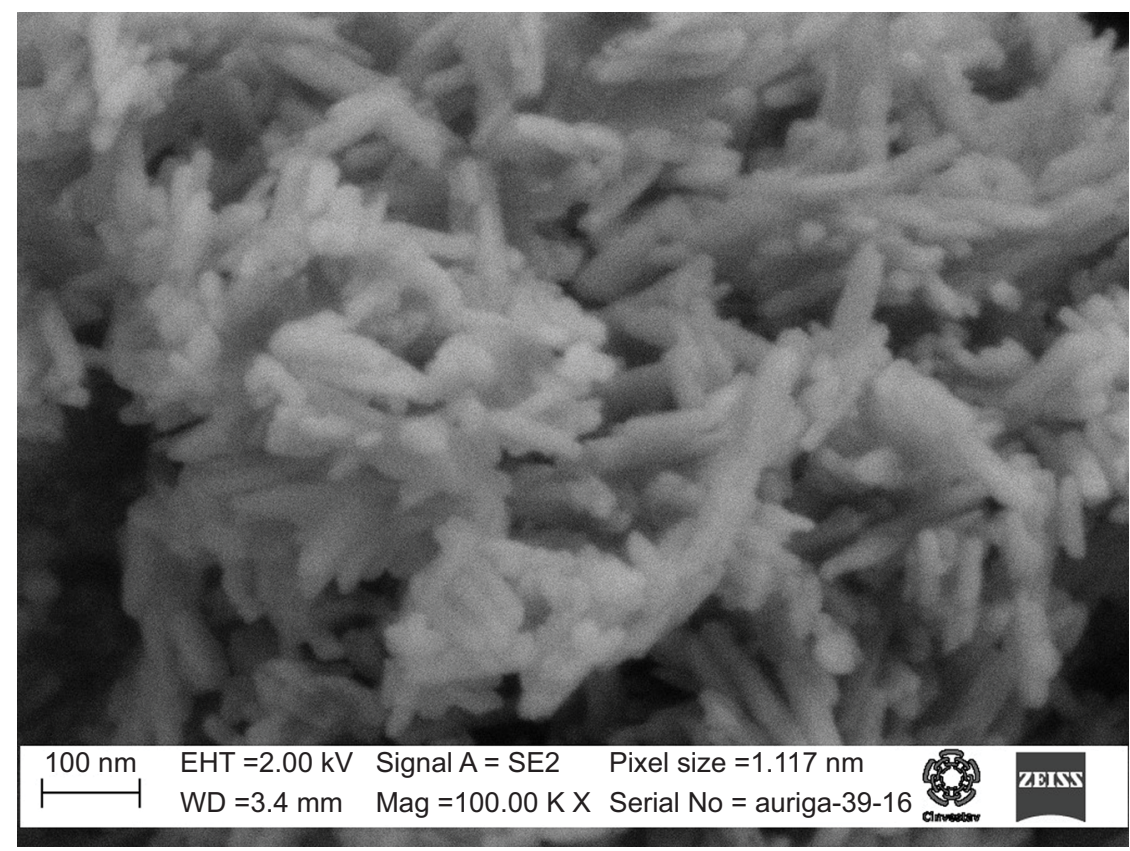

Figure I SEM image of the HA obtained.

Abbreviations: SEM, scanning electron microscopy; HA, hydroxyapatite.

\section{Osteoblast cell density assay}

The human fetal osteoblast cell line (hFOB, ATCC ${ }^{\circledR} \mathrm{CRL}$ $11372^{\mathrm{TM}}$ ) was used to evaluate osteoblast responses to the coated Ti substrates. The hFOB cells were cultured with Osteoblast Growth Medium (PromoCell, Heidelberg, Germany) supplemented with $1 \%$ penicillin-streptomycin at $34{ }^{\circ} \mathrm{C}$ and $5 \% \mathrm{CO}_{2}$. In all experiments, cells with passage numbers 4-7 were used. Before experiments, the sterile Ti substrates coated with pHEMA were pre-soaked in cell culture media for 30 minutes at $34^{\circ} \mathrm{C}$. The $\mathrm{hFOB}$ cells were then seeded onto the substrates at $5 \times 10^{4}$ cells $/ \mathrm{cm}^{2}$. Cells were incubated for 3 days to allow for adhesion and growth onto substrates while cell culture medium was replaced every 48 hours. The MTS cell viability assay kit (Promega Corporation, Fitchburg, WI, USA) was used to determine cell densities. At the end of incubation, the Ti substrates with cells were washed with PBS and incubated with $1 \mathrm{~mL}$ of cell medium mixed with $200 \mu \mathrm{L}$ of the MTS reagent. After the samples were incubated for 3 hours, the absorbance of the culture supernatant in each sample was taken and measured at a wavelength of $490 \mathrm{~nm}$ by a spectrophotometer (SpectraMax M3; Molecular Devices LLC, Sunnyvale, CA, USA). To estimate the cell numbers in each well, a standard curve expressing the linear correlation between different<smiles>CCCCCCCCCCCCCCCCCCC(=O)NCC(=O)NC(CCCCNC(=N)O)C(=O)NC(CCCNC(=N)N)C(=O)NC(CCCNC(=N)O)C(=O)NC(CCCNC(=N)O)C(=O)NC(CCCNC(=N)O)C(=O)NC(CCCNC(=N)O)C(=O)NC(CCCCNC(=N)O)C(=O)NC(CCCNC(=N)N)C(=O)NCC(=O)NC(CC(=O)O)C(=O)NC(CO)C(=O)O</smiles>

Figure 2 Chemical structure of APNPs.

Abbreviation: APNP, amphiphilic peptide nanoparticle. 
cell densities and ODs $\left(\mathrm{R}^{2}>0.95\right)$ was plotted, and the cell numbers were determined with this standard curve from the OD490 value recorded for each sample.

\section{Scanning electron microscope (SEM) images}

An SEM (PHILLIPS/XL30-ESEM, Eindhoven, The Netherlands) was used to obtain surface micrographs from the cell experiments above including coatings with pHEMA, coatings with pHEMA and HA, coatings with pHEMA and APNPs, and coatings with pHEMA, HA, and APNPs.

\section{Statistical analysis}

Each experiment was performed in triplicate. Data are expressed as mean \pm standard error of the mean, and a twotailed Student $t$-test was used to evaluate the differences between means, with $P<0.05$ being considered statistically significant.

\section{Results}

\section{HA results}

Figure 3 shows the X-ray diffraction pattern obtained for the synthesized HA. ${ }^{8}$
Figure 3 shows that all the peaks from the sample pattern match with those of the 09-0432 JCPDS diffraction card provided by the International Center for Diffraction Data (ICDD). It is seen that some peaks have different intensities with respect to those in the ICDD pattern. Moreover, positions of the peaks did not differ from those in the ICDD pattern. Based on these observations, it can be concluded that the sample contained HA; although there were some impurities ( $\mathrm{C}-\mathrm{O}$ bond, Figure 4$)$ in the $\mathrm{HA}$, it did not have size and shape distortion. Figure 4 shows the infrared spectrum obtained for the synthesized HA again showing expected peaks and confirming results of other studies. ${ }^{8}$

In Figure 4, $\mathrm{P}-\mathrm{O}$ and $\mathrm{O}-\mathrm{H}$ bonds, which were present in $\mathrm{HA}$, were identified. $\mathrm{C}-\mathrm{O}$ bonds were also identified and could be present due to the interaction of $\mathrm{CO}_{2}$ and the compounds present in the reaction.

Figure 5 shows the transmission electron microscope (TEM) images as well as the electron diffraction pattern obtained for the synthesized HA. Figure 5A shows that the sample grew in the (200) preferential direction, while Figure 5B shows that nanocrystals were obtained, whose dimensions were about $50 \mathrm{~nm}$ in length and $30 \mathrm{~nm}$ in width. Figure $5 \mathrm{C}$ and D shows a TEM image and the electron diffraction pattern obtained from it.

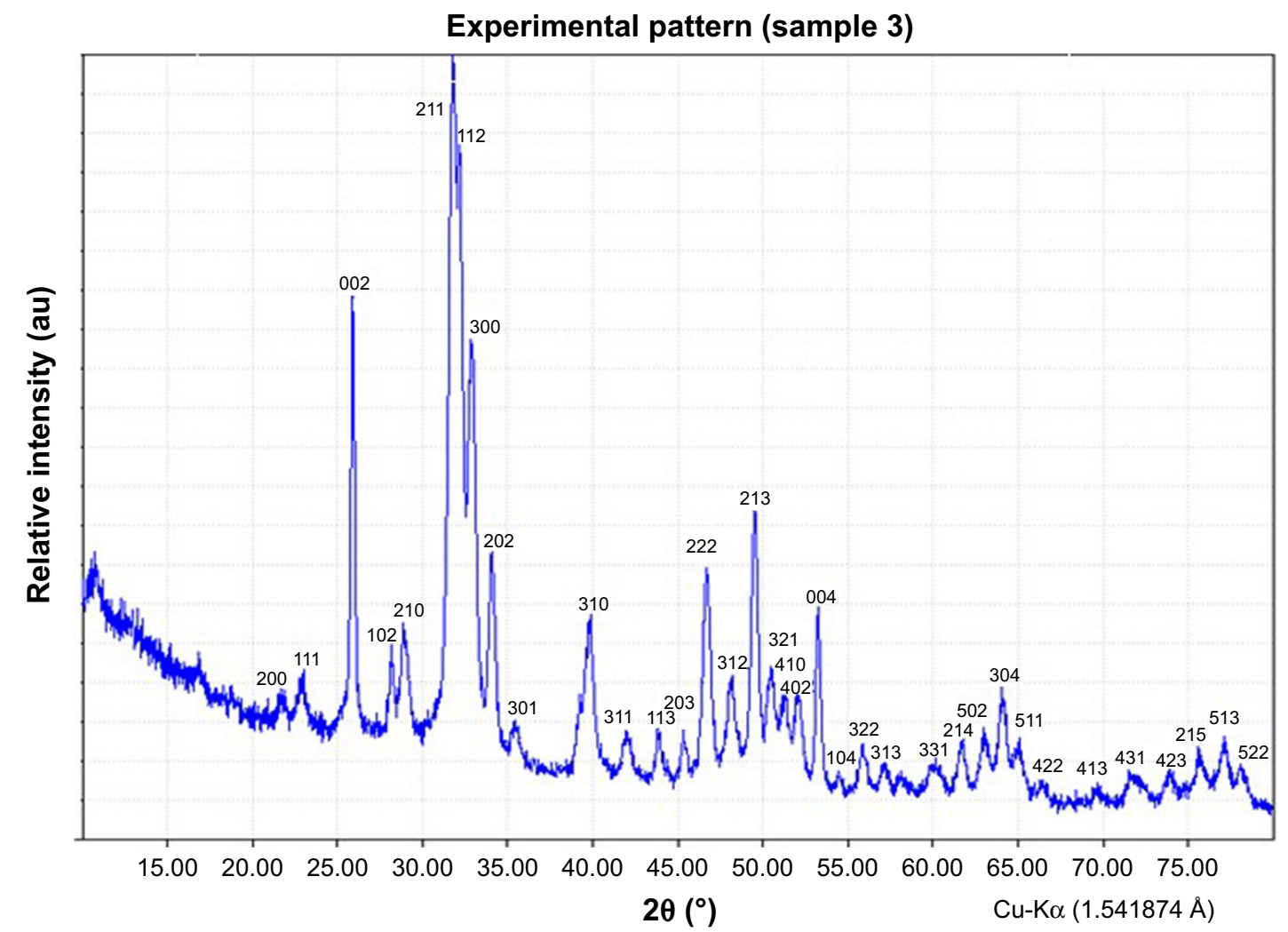

Figure 3 XRD pattern of the synthesized $H A$.

Abbreviations: XRD, X-ray diffraction; HA, hydroxyapatite. 


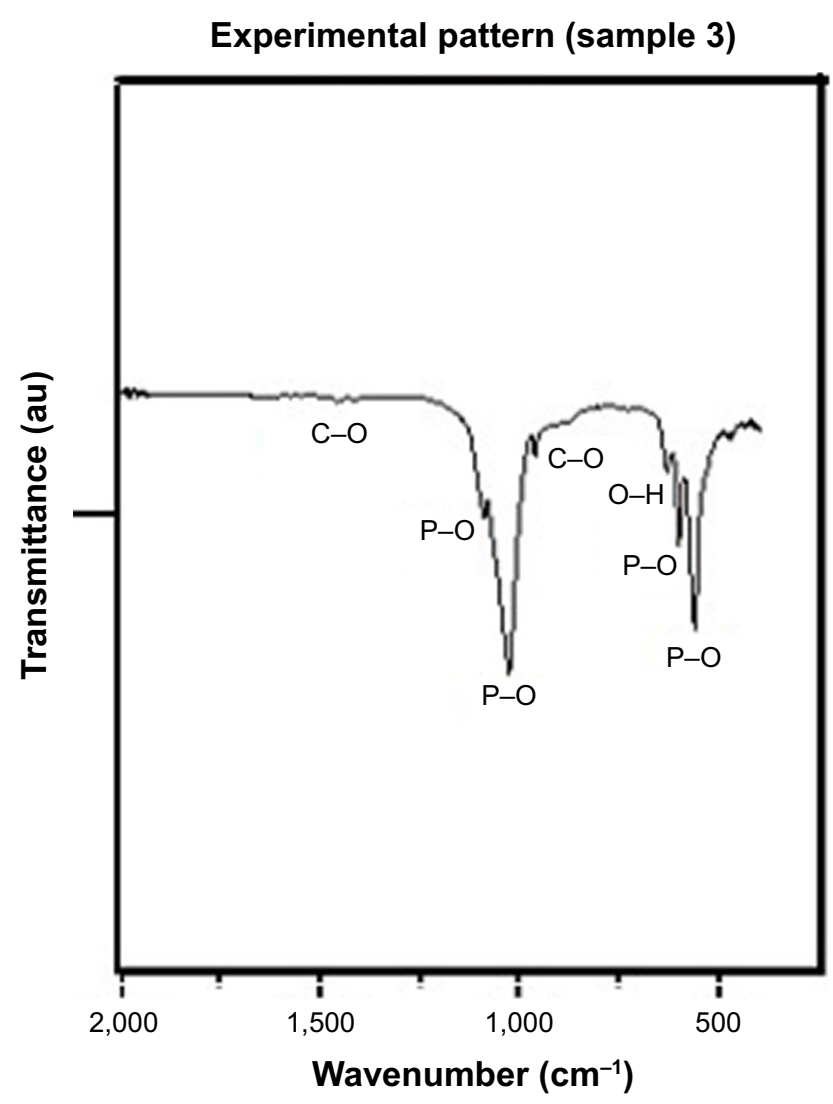

Figure 4 IR spectrum of the synthesized $H A$. Abbreviations: IR, infrared; HA, hydroxyapatite.

Table 1 shows the indexation of the electron diffraction pattern shown in Figure 5D again with the expected results.

Table 1 shows that the interplanar distances obtained from the electron diffraction pattern (Figure 5D) match those obtained from the ICDD; for this reason, it was concluded that the sample contains HA.

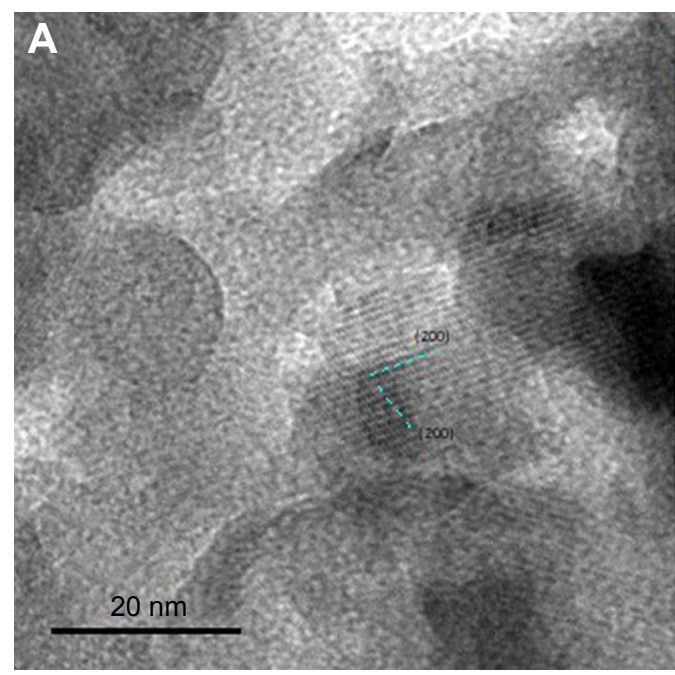

APNP characterization

APNPs were characterized as previously described. ${ }^{19}$

\section{SEM images}

The micrographs obtained are shown in Figure 6. It can be seen that the morphology of the samples showed plain areas and small areas with bumps and small particles; however, at these magnifications, the morphology did not change significantly from sample to sample.

\section{Osteoblast cell density results}

Results from the osteoblast density tests provided the first evidence of greater osteoblast density on pHEMA coatings with nanocrystalline HA and APNPs compared to coatings with plain pHEMA, pHEMA and HA, and pHEMA and APNPs (Figure 7). The osteoblast density on the coatings with pHEMA, nanocrystalline HA, and APNPs increased 17\%, $38 \%$, and $25 \%$ compared to coatings with plain pHEMA, pHEMA and APNPs, and pHEMA and HA, respectively.

\section{Discussion}

This study showed for the first time that simply adding both nano HA and APNPs to a common hydrogel, pHEMA, significantly increases osteoblast densities. Interestingly, when adding both of the components individually (either nano HA or APNPs), osteoblast densities did not increase. Thus, there is something certainly unique that needs to be further studied concerning the interactions between nano HA and APNPs to promote osteoblast attachment and growth necessary for bone growth to occur. Although not determined in this study, it is plausible that APNPs by themselves were embedded into

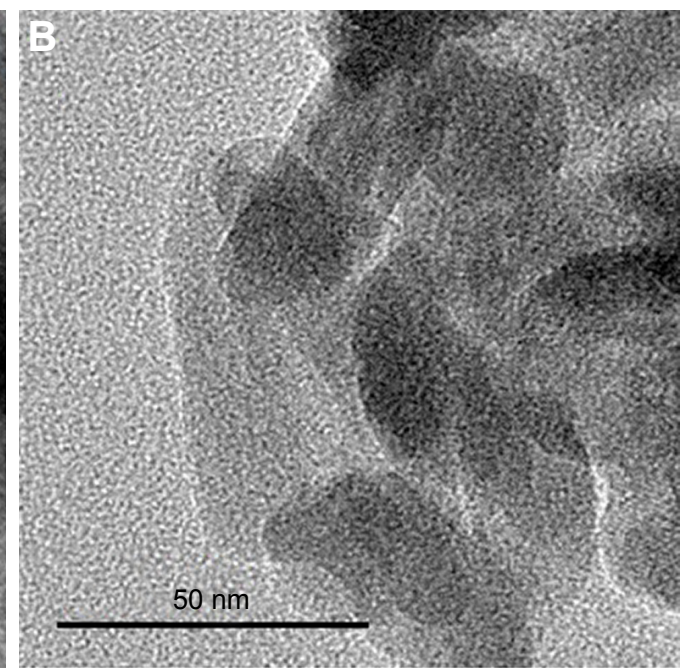

Figure 5 (Continued) 

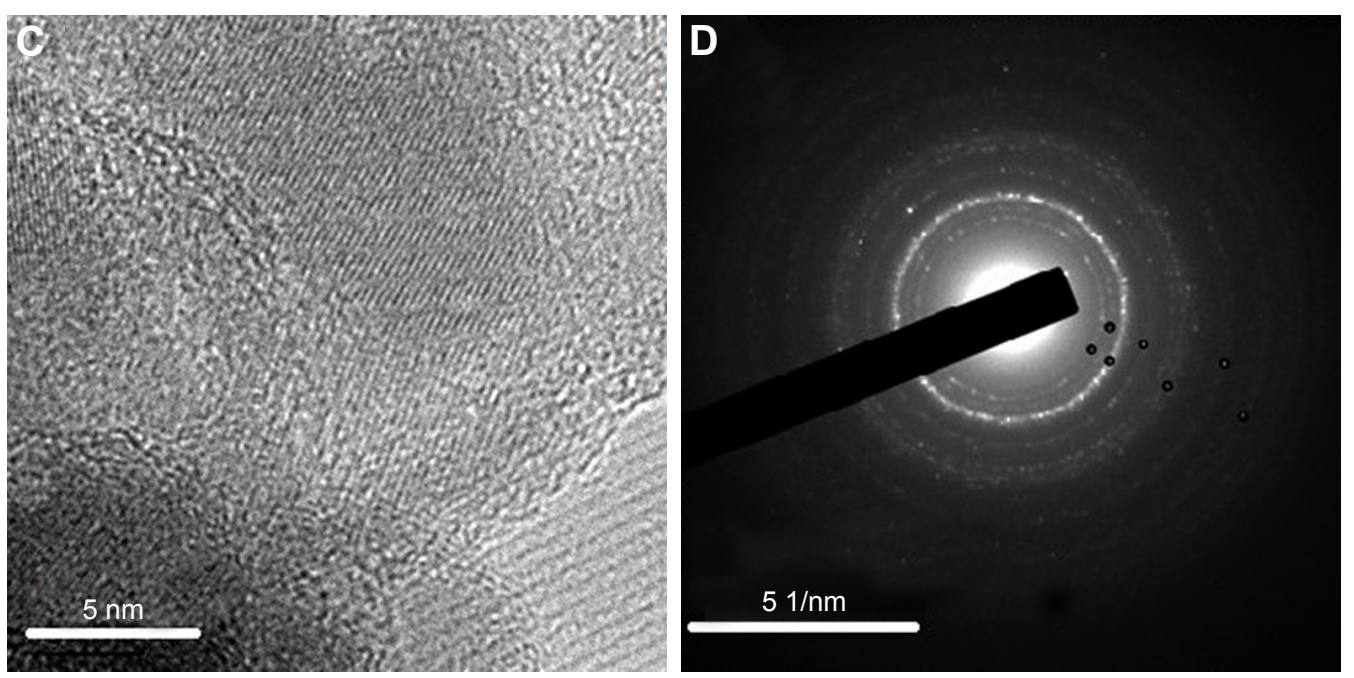

Figure 5 TEM images of (A-C) synthesized HA. (D) Electron diffraction pattern of HA.

Abbreviations: TEM, transmission electron microscope; HA, hydroxyapatite.

Table I Indexation of electron diffraction pattern

\begin{tabular}{|l|l|l|l|l|}
\hline Ring & d of ICDD from XRD $(\mathbf{A})$ & d of HA from TEM (A) & Error (\%) & hkl \\
\hline I & 3.170 & 3.187 & 0.53628 & 102 \\
\hline 2 & 2.814 & 2.855 & 1.45700 & 211 \\
\hline 3 & 2.631 & 2.538 & 3.53478 & 202 \\
\hline 4 & 2.065 & 2.099 & 1.64649 & 113 \\
\hline 5 & 1.722 & 1.710 & 0.69686 & 004 \\
\hline 6 & 1.335 & 1.335 & 0.96439 & 512 \\
\hline
\end{tabular}

Abbreviations: XRD, X-ray diffraction; HA, hydroxyapatite; ICDD, the International Center for Diffraction Data.
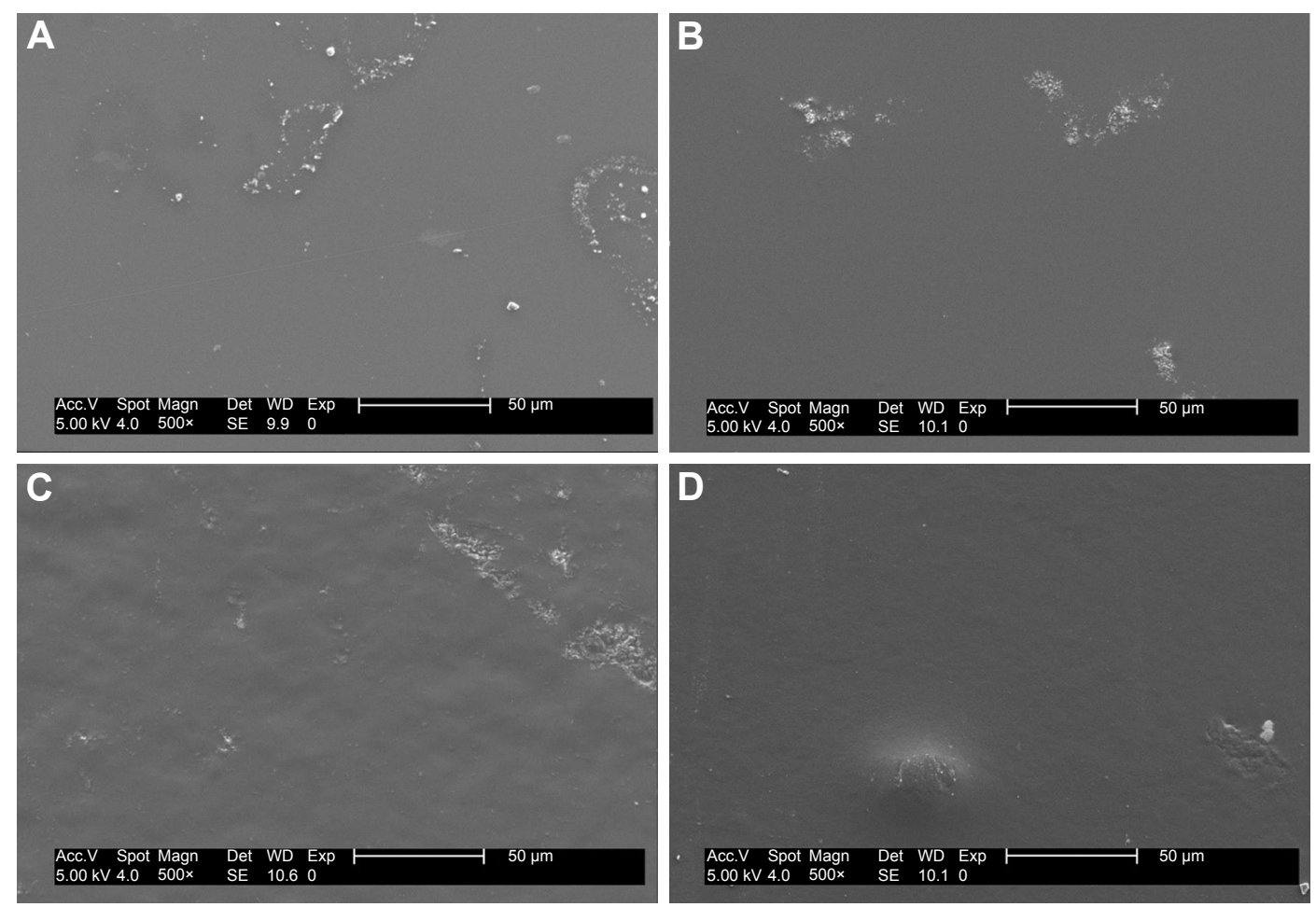

Figure 6 SEM images of (A) pHEMA coatings; (B) pHEMA + HA coatings; (C) pHEMA + APNPs coatings; and (D) pHEMA + HA + APNPs coatings.

Abbreviations: SEM, scanning electron microscope; pHEMA, 2-hydroxyethyl methacrylate; HA, hydroxyapatite; APNP, amphiphilic peptide nanoparticle. 


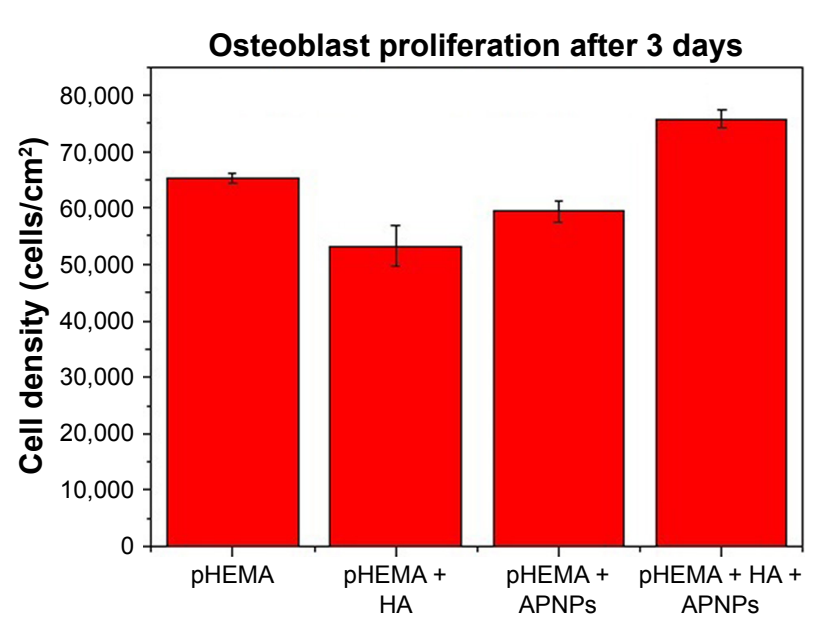

Figure 7 Osteoblast density on pHEMA, APNPs, and nanocrystalline HA-coated titanium. Data are mean \pm S.E.M.; $n=3$. $P<0.005$ for all comparisons.

Abbreviations: pHEMA, 2-hydroxyethyl methacrylate; APNP, amphiphilic peptide nanoparticle; HA, hydroxyapatite; S.E.M., standard error of the mean.

pHEMA and, thus, hidden from osteoblasts to promote their adhesion and growth via their RGD peptide sequence. Furthermore, HA nanoparticles may have been exposed, but not in high enough concentration to promote osteoblast densities as seen in other studies. ${ }^{8}$ Yet, collectively the HA nanoparticles may have been coated with APNPs and thus helped surface exposure of RGD (and bioactivity) in the APNPs to promote osteoblast densities. Clearly, the mechanism for the greater osteoblast densities needs to be further elucidated in order to optimize such results. Additional mechanisms may involve alterations in surface energy which can change initial protein adsorption important for promoting osteoblast adhesion events. This has been a common mechanism elucidated when adding nanoparticles to hydrogels which leads to increased hydrophilicity and consequently greater vitronectin adsorption, a protein commonly associated with greater osteoblast adhesion. ${ }^{8}$ Furthermore, it would be interesting to examine how many other hydrogels, nano HA, and APNPs can be added to promote the functions of osteoblasts. Nonetheless, it is clear that the present addition of only nano HA and APNPs to pHEMA represents a simple way to promote osteoblast densities on a popular injectable tissue engineering material.

\section{Conclusion}

In summary, HA was synthesized by a precipitation method and characterized by several techniques. The present study demonstrated that nanocrystalline HA was obtained. Moreover, several coatings with different conditions were obtained. There was a statistical difference between osteoblast cell density obtained for coatings prepared with pHEMA, HA and APNPs compared to the osteoblast cell density obtained for the rest of the coatings. Creating a biomimetic coating made of pHEMA hydrogels with HA and APNPs is a promising idea to improve osteoblast density which deserves further investigation to perhaps ultimately increase the life expectancy of an orthopedic implant.

\section{Acknowledgments}

This research was supported by CONACYT. We would like to thank the staff of CINVESTAV Zacatenco, LIDTRA CINVESTAV Queretaro, Northeastern University, and Mogel Fluidos SA de CV for providing materials for synthesis as well as equipment for analyzing the data.

\section{Disclosure}

The authors report no conflicts of interest in this work.

\section{References}

1. Xia Z, Yu X, Wei M. Biomimetic collagen/apatite coating formation on Ti6al4V substrates. J Biomed Mater Res B Appl Biomater. 2011;100B: 871-881. doi:10.1002/jbm.b.31970

2. Pan M, Kong X, Cai Y, Yao J. Hydroxyapatite coating on the titanium substrate modulated by a recombinant collagen-like protein. Mater Chem Phys. 2011;126(3):811-817. doi:10.1016/j.matchemphys.2010.12.037

3. CiobanuG, CiobanuO. Investigation on the effect of collagen and vitamins on biomimetic hydroxyapatite coating formation on titanium surfaces. Mater Sci Eng C Mater Biol Appl. 2013;33(3):1683-1688. doi:10.1016/j.msec. 2012.12.080

4. Tang S, Tian B, Guo Y-J, Zhu Z-A, Guo Y-P. Chitosan/carbonated hydroxyapatite composite coatings: fabrication, structure and biocompatibility. Surf Coat Technol. 2014;251:210-216. doi:10.1016/j. surfcoat.2014.04.028

5. Askal B, Kom M, Tosun HB, Demirel M. Influence of micro- and nanohydroxyapatite coatings on the osteointegration of metallic (Ti6Al4V) and bioabsorbable interferences screws: an invo study. Eur J Orthop Surg Traumatol. 2014;24(5):813-819. doi:10.1007/s00590-013-1236-8

6. Macchi RL. Materiales Dentales. Buenos Aires, Argentina: Editorial Panamericana; 2007:390-397.

7. Craig RG, Powers JM, Wataha JC. Dental Materials. Michigan: Mosby; 2000.

8. Zhang L, Chen Y, Rodriguez J, Fenniri H, Webster TJ. Biomimetic helical rosette nanotubes and nanocrystalline hydroxyapatite coatings on titanium for improving orthopedic implants. Int J Nanomedicine. 2008;3(3):323-333.

9. Yaszemski MJ, Trantolo DJ, Lewandrowski K-U, Hasirci V, Altobelli DE,Wise DL. Biomaterials in Orthopedics. Boca Raton: Marcel Dekker; 2004:1-435.

10. Ratner BD, Hoffman AD, Schoen FJ, Lemons JE. Biomaterials Science. San Diego: Elsevier Academic Press; 2004:162-167.

11. LeGeros RZ. Calcium Phosphates in Oral Biology and Medicine. New York: Karger; 1991:12.

12. Beheri HH, Mohamed KR, El-Bassyouni GT. Mechanical and microstrcutre of reinforced hydroxyapatite/calcium silicate nanocomposites materials. Mater Des. 2013;44:461-468. doi:10.1016/j. matdes.2012.08.020

13. Fernandez J, Guilemany JM, Gaona M. La proyección térmica en la obtención de recubrimientos biocompatibles: ventajas de la proyección térmica por alta velocidad (HVOF) sobre la proyección térmica por plasma atmosférico (APS). Biomecánica. 2005;13(1):16-39. Spanish.

14. Fawcett DW. Compendio de Histología. Madrid: McGrawHill; 1999:74-85.

15. Kokubo T. Bioceramics and Their Clinical Applications. Cambridge: Woodhead Publishing Materials; 2008:367-386.

16. Poole CP, Owens FJ. Introducción a la Nanotecnología. Barcelona: Editorial Reverté; 2007:80. 
17. Chen J-X, Wang HY, Quan C-Y, Xu X-D, Zhang X-Z, Zhuo R-X. Amphiphilic cationic lipopeptides with RGD sequences as gene vectors. Org Biomol Chem. 2010;8:3142-3148. doi:10.1039/c003538f

18. Schaffner P, Dard MM. Structure and function of RGD peptides involved in bone biology. Cell Mol Life Sci. 2003;60(1):119-132.
19. Chang R, Sun L, Webster TJ. Selective inhibition of MG-63 osteosarcoma cell proliferation induced by curcumin-loaded self-assembled arginine-rich-RGD nanospheres. Int $J$ Nanomedicine. 2015;10: 3351-3365. doi:10.2147/IJN.S78756

International Journal of Nanomedicine

\section{Publish your work in this journal}

The International Journal of Nanomedicine is an international, peerreviewed journal focusing on the application of nanotechnology in diagnostics, therapeutics, and drug delivery systems throughout the biomedical field. This journal is indexed on PubMed Central, MedLine, CAS, SciSearch ${ }^{\circledR}$, Current Contents ${ }^{\circledR} /$ Clinical Medicine,

Journal Citation Reports/Science Edition, EMBase, Scopus and the Elsevier Bibliographic databases. The manuscript management system is completely online and includes a very quick and fair peer-review system, which is all easy to use. Visit http://www.dovepress.com/ testimonials.php to read real quotes from published authors.

Submit your manuscript here: http://www.dovepress.com/international-journal-of-nanomedicine-journal 